\title{
Konfrotant Joumal: \\ The Political Dynamic of Dayak Elite on Relocating Capital to Kalimantan Island
}

\author{
Purnama Julia Utami ${ }^{1}$, Sri Musrifah ${ }^{2}$ \\ ${ }^{1}$ Universitas Palangka Raya, Indonesia \\ ${ }^{2}$ Universitas PGRI Ronggolawe Tuban, Indonesia \\ pjutami@fisip.upr.ac.id
}

\begin{abstract}
This study aims to see how pertinent the Dayak elites believe in the transition of relocating their capital to Central Kalimantan. This study uses a historical-dialectical approach to address the Dayak that strengthen their identity. The purpose of this study is to demonstrate the importance of the Dayak in strengthening their identity and reputation. With a newfound identity, Dayak farmers would gain recognition from both the provincial governments and the entire state of Indonesia. From now on, the Dayak would be recognized as a legitimate and valuable population.
\end{abstract}

\section{Keywords}

identity politics; Dayak elite; relocating capital city; multiculturalism; policy analysis; political identity

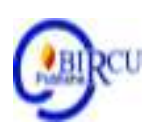

\section{Introduction}

In 2017, Indonesian President Joko Widodo, forwarded the idea that the state capital needs to move. This plan has emerged since the era of Soekarno in 1957. The plan lays forth the process of moving the State capital to Palangka Raya City in July 1957. Sukarno placed the first piles in Pahandut, Central Kalimantan. However, this discourse continued to disappear and sink until 2019. President Widodo then reintroduced the idea of moving the state capital in a limited cabinet meeting and made the plan a strategic issue, and has included this proposal in the National Medium-Term Development Plan (RPJMN) 20202024, the Minister of National Development Planning (Bappenas), Indonesian economist and former Minister of Research and Technology Bambang Brojonegoro, emphasized that relocating the capital city is a long-term strategy which aims to reduce the burden that has been borne by Jakarta (Sukmana, 2019).

Initially the location of the prospective capital city of the Republic of Indonesia was kept secret so that the government could carry out an in-depth research process related to geopolitics in Indonesia. In the process there were at least 4 Provinces that submitted themselves as regions that were ready to be made the new capital of the Republic of Indonesia. Palangka Raya as the capital city of Central Kalimantan Province is often considered as the most suitable area to be used as the capital city of the Republic of Indonesia, this is related to the past romance of Sukarno's government who wanted Palangka Raya to be the capital of the future Republic of Indonesia. Faisal Basri who specializes in political economics at the University of Indonesia explained:

...there are three reasons Palangka Raya is very suitable as the capital city of Indonesia, based on Soekarno's description. First, the city is considered safe from earthquakes or disasters because it is not part of the path where three tectonic plates meet. Second, Palangka Raya's land is not fertile or peat, so that it can be engineered into a city. If the land is fertile, it is suitable for agriculture, and the third reason, the geographical conditions of Palangka Raya tend to be flat, so it is hoped that the costs for infrastructure development and other necessities are not too expensive (Faisal Basri as cited in Aryanti 2017). 
Konfrontasi Journal: Culture, Economy and Social Changes, 8 (4) December 2021, 364-373

ISSN: 1410-881X (Print), 2716-2095 (Online)

Purnama Julia Utami, Sri Musrifah: The Political Dynamic of Dayak Elite on Relocating Capital to Kalimantan Island

DOI: https://doi.org/10.33258/konfrontasi2.v8i4.173

http://www.konfrontasi.net/index.php/konfrontasi2

Palangka Raya has an area of 285,300 hectares, the population as of 2019 was recorded at 266,090 people with a population density of 93 hectares plus the changes in city spatial planning. After further consideration, Palangka Raya was no longer considered as an ideal site for the capital of the Republic of Indonesia. However, Central Kalimantan as a province has a large area of around 15.356.400 hectares, and a relatively small population of which has sufficient criteria as an area capable of providing land for a prospective new capital city. However, there are numerous obstacles in securing an idealized land. In many places, the potential areas to provide the capital are residential areas, protected forests, peatlands and supporting areas for watersheds. Although the problem with accumulating an ideal area apparent, the Governor of Central Kalimantan, Sugianto Sabran as cited in (Aziza, 2017), stated that he was able to prepare 300,000 hectares in Central Kalimantan Province.

Geographically, Central Kalimantan is located right in the centre of the Unitary State of Republic of Indonesia. This land's location makes it a worthy contender for being a state capital. This land is present in a location with few hazards in Indonesia. In addition, Dayak people as natives of Central Kalimantan tend to adapt easily to all changes. In addition, Central Kalimantan is recognizable by the State. East Kalimantan, South Kalimantan and West Kalimantan actually existed before the Republic of Indonesia. All three provinces already have the social power of both the kingdom and the sultanate. Through this consideration, the only province that remains a fully controlled by the state is Central Kalimantan. However, on August 26, 2019, the President of the Republic of Indonesia Joko Widodo announced the establishment of the Capital of the State to Move to Kalimantan Island, specifically East Kalimantan. North Penajam Paser (PPU) Regent Abdul Gafur Mas'ud as cited in (Wismabrata, 2019) claimed to have prepared a land area of 300,000 hectares, before President Joko Widodo announced that part of the PPU area would become the new capital.

At the end of 2019, the world was shocked by the spread of coronavirus (Covid-19). This pandemic shifted the focus of the world elite. Efforts to fortify a new capital moved to combating the spread of the Covid-19 in their countries, including Indonesia. On March 2, 2020, President Jokowi announced that Covid-19 cases had spread in Indonesia as the first case was reported. The number of Covid-19 cases in Indonesia continued to grow daily, and on March 30, 2020 data from the Ministry of Health revealed the number of Covid-19 Pandemic cases in Indonesia reached 1,414 cases. In April 30, 2020 cases increased to 10,118 cases. And on May 26, 2020 The number of Covid-19 cases reached 23,165 positive cases. These staggering caseloads did not include Patients Under Surveillance (PDP), People Under Monitoring (ODP) and People Without Symptoms (OTG). The Covid-19 pandemic does not have a foreseen and definite ending. With the significance of positive Covid-19 cases, the question arises, how can the relocation of the capital to the island of Kalimantan occur?

Politics is a special language that serves as a benchmark, Politics encompasses demands, arguments, definitions and operational rules that govern the ins and outs of human life. Political terminology uses specific rules for how this terminology is proliferated by human entities. In particular, how these key indicators are observed freely in various available models in the environment? Which are then used as keys to observe the reality of political life. The Classical view put forward by Plato and Aristotle views politics as the fulfilment of the realization of the public interest. Where politics is associated as a public activity that aims to influence society, the common space that 
appears in society allows each individual to have the same opportunity to improve their talents, abilities and quality of life.

In this study, Dayak elites in the scope of moving the capital to Central Kalimantan will be analyzed through the theory of Political Identity and the framework of the concept of Dayak Elites. Even though the Determination of the State Capital has been announced by President Jokowi on August 26 2019, and it is confirmed that the capital is moving to the island of Borneo. The elites analyzed in this article are the Dayak political elites who have been, and are currently leading Central Kalimantan Province.

\section{Review of Literature}

\subsection{Political Identity}

Identity is a tool for a community group in the process of strengthening its dominance in the environment. Social life is an arena where competition between elites and society increases legitimacy as access to gain and maintain political power. Identity serves as the rule of the game in gathering solidarity and maintaining commitment in the process of keeping identity exclusive. This construction of identity aims to give influence (D'Entrèves, 2020) to other groups and often this construction is played out in local political contestation (Xia, 2020). Amrizal et al (2018) stated that political participation is the involvement of self, mental, thoughts and emotions or feelings of a person from various levels of political activity such as election activities of state leaders through elections as a form of awareness and responsibility of a person against government regulations or policies. The participation of the people in the general election is by participating in the implementation of the general election to achieve the goals of the nation and hasten in democracy.

Identity is a kinship symbol of politicians which is a political strategy in seeking and maintaining power. The Dayak elite as political identities have a broad scope of influence on political activity and have a close relationship in theoretical studies. The expression politics of identity appears to provide an explanation regarding political activity based on various experiences of injustice experienced by members of certain social groups. Identity politics is related to the effort to restore harmony, respect, autonomy and responsibility in order to understand and preserve customary values (Clements, 2007). Identity in identity politics becomes the subject's experience of oppression and shared experience in the process of determining alternative solutions for the common good (Cohen 2002). In every community or society, the available resources and production factors must be allocated as best as possible to provide maximum results which are then distributed in the form of income and prosperity in the community. identity requires differences (Dougherty, 2008), so that if there are no differences in society, there will be a new political claim that strengthen the political hierarchy but are ideologically flawed.

Identity politics is about the recognition of one's status as rightfully belonging and the public manifestation of modes of belonging. In addition, identity politics is about recognition by others of who and what one is (Taylor, 1992).

\subsection{Elite Theory}

The political elite is individuals or groups who have influence in the political decision-making process (Gilens, 2002). The concept of elite by appointing a minority of individuals (Leighley, 2001) who were appointed to serve a collectivity in a socially valuable way. Elites as a minority are described as having very effective and responsible 
nature and role towards their groups. Elite theory is a theory that assumes that it is the political elite that determines the dynamics of a region's political life.

Political elites include all power holders in a political structure, this elite consists of those who have succeeded in achieving dominant positions in the political system and in community life. They have power, wealth and honor. Political elites also include those who have political positions in the political system. Political office is the highest status obtained by every citizen. In any political system and political structure, the highest power is always occupied by a group of people called the political elite or the ruling elite. Elites are those who occupy command positions in the main institutions in society. With this position, the elites make decisions that will impact all levels of society. In modern conditions, strategic elites are equipped with qualified capabilities in various segments (Keller, 1991).

In terminology, elite refers to a group of people in society who have positions and have power. In its history, Karl Marx was a figure on which to base studies of the elite, through the concept of class. Goetano Mosca is one of the scientists who is interested in testing Marx's class theory and has succeeded in identifying that there are two classes in society, the ruling class and the ruled class. Meanwhile, Vilfredo Pareto see the elite as a social group that has the highest index in society so that it has influence in the sociopolitical life of the community (Zuckerman, 1977). The index is largely based on considerations of wealth, prowess and political power. According to the political stratification compiled by Pareto, society consists of two classes (Kolegar, 2001): the first class is the upper layer, which is divided into the governing elite and the non-governing elite. The second class is the lower strata of society, the non-elite, in this case the masses. Between the governing elite and the non-governing elite, both have their own place to play their role as an elite and a strategy in gaining mass legitimacy. The masses themselves, although tend to be passive, in certain situations can affect the position of the elite.

The elite has a big influence in the social and political life of the community, although the presence of the elite is only a minority when compared to the non-elite (the masses). The elite dynamics that occur in society always influence the development of society. In general, elites are individuals who are appointed to serve a community group.

The elite itself is divided into the Political Elite and the Non-Political elite. Political elite is someone who holds political positions (power) in the executive and legislative branches who are elected through general elections and elected in a democratic political process at the local level. They hold high political positions at the local level that make and carry out political policies. Meanwhile, non-political elites are individuals who have the influence to rule others in society.

According to Dwaine Marvick, there are two academic traditions about the elite (Bailey, 1969). First, the elite is needed as a special figure who carries out a historical mission, fulfills urgent needs, gives birth to superior talents, or displays his own qualities. The elite are seen as an order-making group that all parties follow. Second, the elite is seen as a group, both a group that brings together government officials or rulers in various sectors and places. The notion of an elite is paired with a leader, decision maker, or influential party who is always a central figure. From the elite theory above, a common thread can be drawn that the Dayak elite are individuals who have influence in society who are appointed to serve the interests of the Dayak community, who have a historical mission and highlight their best qualities, become central figures and have a loyal mass base. 


\section{Research Methods}

This article explores the dynamics of the dayak elite in the vortex of capital transfer to Central Kalimantan, the terminology of dayak elites will be explored based on the period of awakening of Dayak Identity in 1894 to 2020, the focus of this study is how the dynamics that occurred in the period of determination of Palangka Raya City as a Candidate for the Capital of the Republic of Indonesia in 1957, the submission of Central Kalimantan to be the Candidate for the Capital of the Republic of Indonesia in 2019 and the emergence of tires. yak institutions that carry dayak values until 2020. In the reference research process used is a study issued by the University in Indonesia, Journals, Books and Seminar Results published online and offline, as well as mass media that write about the dynamics of the transfer of the National Capital, the Awakening of Dayak Identity and relevant references related to answering the formulation of the problems of this study. In this research elite dynamics will be analyzed through identity politics theory and will give birth to a new concept, namely the emergence of dayak elites that will be used to answer how the internal dynamics of the dayak elite in the community of society in central Kalimantan. The identification of the Dayak Elite is chosen based on its position in executive, legislative and non-formal institutions that have knowledge in the process of submitting Central Kalimantan as the capital of the Republic of Indonesia.

\section{Results and Discussion}

Identity construction is not just awakened, but through the process of display far away since the days of Dutch colonialism. The process of identifying local people and dutch people is represented with different skin colors. The key word tried in this analysis of history is the dominance of dutch society towards its existence in Indonesia is strengthened after the establishment of the First Organization by the Elite in Java which aims to teach and revive Javanese culture. This organization is named Boedi Oetomo, whose contents are Intellectuals, government employees and Aristocrats.

The initial dynamics of the struggle of the first student organization in Indonesia then gave birth to many similar organizations but with fundamental ideological differences. The Indonesian Association, Sarekat Islam, Indische Partij and Muhammadiyah are organizations that were born after having regular interactions and communications with the Boedi Oetomo. In the Dutch colonial period, the education presented by the Dutch government was limited to the wealth of nobles and government employees only, so the emerging tendency of organizations that stood at that time was only filled by elite people in their time. This present organization complements each other in the process of realizing Indonesia's independence.

In history books, it is often quoted how this youth organization has a big role in realizing the welfare of Indonesian society. Identity construction built to accommodate the struggle of the Indonesian movement is considered a successful journey to make indonesian society united to liberate themselves on August 17, 1945. Even the main figures in the organization are often held as national heroes.

This history is a proof that identity depends on the construction built by actors called elites of their time. Social response to the political conditions that are built forces local people to maximize their ability to jointly build the nation and state. The number of identities attached to an individual is then subjectivelyr epresented as human interaction in a particular community progresses, if described succinctly the following is the construction of the birth of identity during colonial rule until the Reformation. 


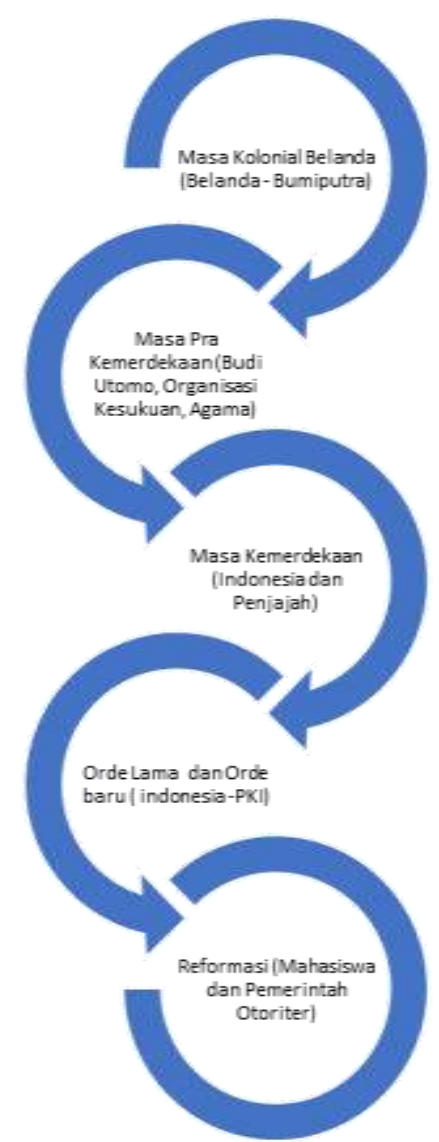

Figure 1. The Birth of an Elite in Representing an Inherent Identity

The image above explains the dominance of identity that is 'forced to emerge' from the dutch colonial period until the reform period in Indonesia, broadly speaking this identification cannot be separated from the identity format and social structure formed in society. The closeness of identity politics in Indonesia is the influence of the Dutch colonial-era ethical politics that are now growing and developing in Indonesia which is at the root of all social changes that occur and affirms and fosters a new elite in the present.

In the historical line, Central Kalimantan is an area that is geographically located in the middle of the island cluster of the Republic of Indonesia, and because it is located far from the ocean, only a small part of the kingdom has invaded Central Kalimantan, namely the Kingdom of Kutaringin, located in Pangkalanbun West Kotawaringin Regency, while other Central Kalimantan regions only have long-standing inter-tribal conflicts, On this historical basis, the Central Kalimantan Dayak is a completely different tribe to the Dayak in other Kalimantan regions because it was never colonized, but the form of colonization carried out by the Dutch Colonial Government to the People of Central Kalimantan is a form of negotiation called the Tumbang Anoi Peace Meeting, which is used to stop hostility among Dayak tribes and secure the Dutch position in the dayak territory. Construction of the Tumbang Anoi Peace Meeting 1894, triggering the unity of Dayak which impacted on the desire to secede from South Kalimantan.

The process of unification of dayak tribes in central Kalimantan during the Anoi Fall Peace Meeting is a process of spreading messages and actions that provide information related to the reality of the dayak identity constructed. It is very clear that tribal spirit becomes important when faced with an entity called 'difference'. The re- 
strengthening of dayak identity values first emerged in 2001 during ethnic conflict. This conflict is the euphoria of the rise of dayak society, where the spirit of regionality was built as a form of 'resistance' to discrimination that occurred in 2001. In political studies, the dayak process of identifying itself is a way to strengthen and mobilize that identity as a form of political framing to assert its inherent identity. The 2005 election was a form of affirmation of the dayak identity of the candidate pair Teras Narang and Achmad Diran, straightforwardly and clearly the pair was able to show their dayak identity as well as their religious identity in political campaigns. All sorts of programs and political moves show the power that was incorporated into the policy program during his leadership.

Three years into Teras Narang's leadership journey as Governor of Central Kalimantan, in 2008 he issued a Political Policy related to the recognition of indigenous institutions and protection related to customary land rights is the attention of the dayak elite who served at that time and managed to get the attention of the central Kalimantan dayak community in general. This policy-making process takes place from top to bottom, where the problems of dayak communities in central Kalimantan are seen as instruments of improvement in the process of strengthening dayak identity. Where the reality of this policy is used as a tool to win the second period of 2010-2015 elections, easily, the collective identity built through this customary symbol is an instrument of rationality as a form of explanation of the choice of the strategy of the ruling elite.

Dayak identity is a central component in the succession process of moving the capital to Central Kalimantan. The identity carried by the elite in the realm of government provides an opportunity for dayak people to increase their political resources and power. Policies are not only made to accommodate the public agenda but are also an ambition of the ruling elite. Political choices implemented by the ruling elite generally prioritize 'moral' values that promote society in fulfilling its right to life. This policy is the choice of the political elite where generally this policy is designed to secure both material and non-material interests.

The dayak collective identity that was awakened after 2001 and strengthened during the Narang Terrace period in 2005-2015 had an impact on the euphoria of contestation of 'dayak identity' where this identity in the running of time gave rise to new alternatives related to the emergence of new indigenous institutions that became material alternatives in the process of winning political contestation. The collective identity that is built is a rational choice for political strategy not only among the dayak community, but also the community institutions formed by the community in central Kalimantan. Referring to post-structuralist theory, collective identity as a cultural construct will determine the interests, relationships and structures that will be formed in society and generally through that identity they easily gain bargaining value in the political structures that have been formed. To understand the process of strengthening dayak identity, the author describes it in the following diagram: 


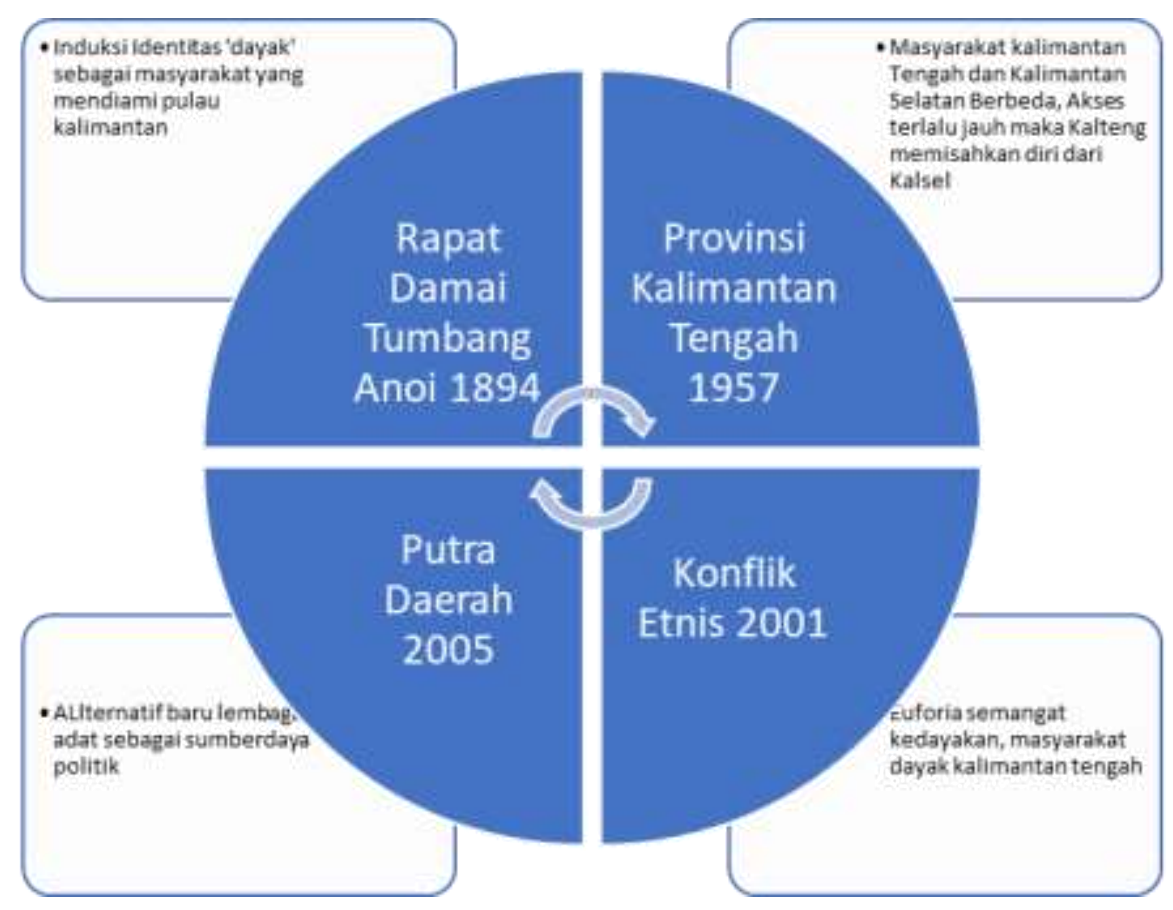

Figure 2. Central Kalimantan Dayak Identity Construction

The euphoria of tribal zeal on the basis of mutually having this 'dayak identity' continues to occur and even quite a number of 'dayak' institutions emerge to prop up the local elites collectively proposed in electoral succession. This wide-open political opportunity is then read as a political opportunity to mobilize local resources which are then used as political goals, one of which is the recognition of 'dayak identity' where this identity is the result of historical dialectics of the past that was influential for the dayak community in the present and the future. And this gave birth to a new elite with a stronger local identity.

As outlined above, Central Kalimantan Province was born with a desire and historical difference that is completely different from South Kalimantan, this process is a historical reality that cannot be left alone, and during the Sukarno Administration central Kalimantan was once used as a candidate for the capital of the Republic of Indonesia, but in fact, the romance of the past without being supported by the development of human resources and infrastructure towards the Capital of the Country, Then it's natural that this dream disappears. But the opportunity as a supporter of the new Capital region strengthened again. The identity pattern of the dayak community of central Kalimantan as a farmer strengthened again because after 2019 quite a lot of farmers were arrested for trying to manage their land with local wisdom. The problem in 2019 was then responded by the Governor of Central Kalimantan and also the government of the Republic of Indonesia who tried to evoke the Suharto-era dream, namely Central Kalimantan as a National Food Barn. Mega Rice Project that was carried out during suharto in 1996 was re-re-established with a new pattern as a form of Contribution of the People of Central Kalimantan to Indonesia.

Politics is a realization when meet the public interest, in this study elites at the level in Central Kalimantan, formal and non-formal elites, helped unite to help the peladang community in Central Kalimantan to legalize regulations related to land burning through the Regulation on Land Fire Control which became legal protection for traditional farmers in Central Kalimantan. And the soul of the people of central 
Kalimantan is accommodated by the central government, with tremendous potential, Central Kalimantan is encouraged to become a Food Estate to support the National Capital region (IKN). The identification of dayak farmers that appear in this study is a form of representation of the new identity recognition of central Kalimantan society, because in the process criminalization makes the elite tend to attach identity in accordance with emerging trends. And it does not rule out the possibility that new discourse will increase the birth of identity that will be associated and framing in such a way into a new identity.

\section{Conclusion}

The long history of Dayak Identity Construction in Central Kalimantan produces elite growth that continues to strengthening, the identity carried by elites in the government sphere provides an opportunity for Dayak people to increase their political resources and power. Policy is not only made to accommodate the public agenda but is also an ambition of the ruling elite. The political choices implemented by the ruling elite generally prioritize the value of 'morals' that promote society in fulfilling its right to life. and does not close the opportunity that the elite in Central Kalimantan will always increase in accordance with the mandate of Democracy as a majority vote provides an opportunity to accommodate the right, collaborate to be able to create a better Indonesia.

In other parts of the analysis, the power that surrounds selected actors will cause endless conflicts of interest so that an in-depth analysis is needed related to differences in identity and potential conflicts that will occur as a form of study of political theory.

\section{References}

Amrizal, D., et al. (2018). The Role of General Election Commission (KPU) in Increasing Voters' Participation in Langkat, Medan, Indonesia. Budapest International Research and Critics Institute-Journal (BIRCI-Journal). P. 13-24.

Ariyanti, F (2017, December 13). Palangkaraya Dinilai Cocok Jadi Ibu Kota Baru RI, Ini Alasannya [Palangkaraya is considered suitable to be the new capital of the Republic of Indonesia, this is the reason]. Liputan6. https://www.liputan6.com/bisnis/read/3194854/palangkaraya-dinilai-cocok-jadi-ibukota-baru-ri-ini-alasannya

Aziza, KS (2017, May 2). Kalteng Siapkan Lahan 300.000 Hektar untuk Pemindahan Ibu Kota ke Palangkaraya [Central Kalimantan to prepare 300,000 hectares of land for the relocation of the capital city to Palangkaraya]. Kompas. https://money.kompas.com/read/2017/05/02/090910426/kalteng.siapkan.lahan.300.0 00.hektar.untuk.pemindahan.ibu.kota.ke.palangkaraya.

Bailey, Harry A., and Ellis Katz, eds. Ethnic Group Politics. Merrill Publishing Company, 1969.

Clements, Kevin P., Volker Boege, Anne Brown, Wendy Foley, and Anna Nolan. "State Building Reconsidered: The Role of Hybridity in the Formation of Political Order." Political Science 59, no. 1 (June 2007): 45-56. https://doi.org/10.1177/003231870705900106.

Cohen, Joshua, 2002 Deliberation and Democratic Legitimacy, in The Good Polity: Normative Analysis of the State, Alan Hamlin and Phillip Petit, editors, New York: Blackwell, 1989. Reprinted in Contemporary Political Philosophy: an Anthology, Robert E. Goodin and Philip Pettit, editors, Malden, MA: Blackwell, 2006. Reprinted 
in Deliberative Democracy: Essays on Reason and Politics, James Bohman and William Rehg, editors, Cambridge, MA: MIT Press, 1997. Reprinted in Democracy, David Estlund, editor, Malden, MA: Blackwell, 2002.

D'Entrèves, Maurizio Passerin. "Legitimacy and Democratic Deliberation." Theoria: A Journal of Social and Political Theory, no. 96 (2000): 14-26. Accessed February 1, 2021. http://www.jstor.org/stable/41802143.

Dougherty, Kevin D., and Kimberly R. Huyser. "Racially Diverse Congregations: Organizational Identity and the Accommodation of Differences." Journal for the Scientific Study of Religion 47, no. 1 (2008): 23-43. Accessed February 1, 2021. http://www.jstor.org/stable/20486885.

Gilens, Martin, and Naomi Murakawa. "Elite cues and political decision-making." Research in micropolitics 6 (2002): 15-49.

Keller, Suzanne Infeld. Beyond the ruling class: Strategic elites in modern society. Transaction Publishers, 1991.

Kolegar, Ferdinand. "The Elite and the Ruling Class: Pareto and Mosca Re-Examined." The Review of Politics 29, no. 3 (1967): 354-69. Accessed February 1, 2021. http://www.jstor.org/stable/1405761.

Leighley, Jan E. Strength in numbers?: The political mobilization of racial and ethnic minorities. Princeton University Press, 2001.

Sukmana, Y (2019, May 5). Kepala Bappenas: Pemindahan Ibu Kota Masuk RPJMN 2020-2024 [Head of Bappenas: Relocating the Capital to be Included in the 20202024 RPJMN].

Kompas. https://money.kompas.com/read/2019/05/09/184859926/kepala-bappenaspemindahan-ibu-kota-masuk-rpjmn-2020-2024.

Taylor, Charles. The ethics of authenticity. Harvard University Press, 1992.

Wismabrata, MH (2019, August 26).300.000 Hektar Lahan di Penajam Paser Utara Siap Dipilih Jadi Lokasi Ibu Kota Baru.[300,000 hectares of land in North Penajam Paser ready to be chosen as the location for the new capital city]. Kompas. https://regional.kompas.com/read/2019/08/26/15380051/300.000-hektar-lahan-dipenajam-paser-utara-siap-dipilih-jadi-lokasi-ibu.

Xia, Ming (2000) Political Contestation and the Emergence of the Provincial People's Congresses as Power Players in Chinese Politics: A network explanation, Journal of Contemporary China, 9:24, 185-214, DOI: 10.1080/713675941

Zuckerman, Alan. "The Concept" Political Elite": Lessons from Mosca and Pareto." The Journal of Politics 39, no. 2 (1977): 324-344. 